\title{
CORRECTION
}

\section{Correction to: ASENT2020 Annual Meeting Abstracts}

Published online: 14 December 2021

(c) The American Society for Experimental NeuroTherapeutics, Inc. 2021

\section{Correction to: Neurotherapeutics volume 17, pages 1311-1323 (2020) https://doi.org/10.1007/s13311-020-00896-5}

In this article, Carolyn Tallon at affiliation Johns Hopkins Drug Discovery and Neurology was added to the author list for Poster 7.

The original article has been corrected.

Publisher's Note Springer Nature remains neutral with regard to jurisdictional claims in published maps and institutional affiliations.

The original article can be found online at https://doi.org/10.1007/ s13311-020-00896-5. 